\title{
Correction to: Relation Between Zinc and Thyroid Hormones in Humans: a Systematic Review
}

\section{Jéssica Batista Beserra ${ }^{1}$ Jennifer Beatriz Silva Morais ${ }^{1}$ • Juliana Soares Severo ${ }^{1} \cdot$ Kyria Jayanne Clímaco Cruz ${ }^{1}$. Ana Raquel Soares de Oliveira ${ }^{1}$. Gilberto Simeone Henriques ${ }^{2}$ - Dilina do Nascimento Marreiro ${ }^{1,3}$}

Published online: 7 May 2021

(C) Springer Science+Business Media, LLC, part of Springer Nature 2021

\section{Correction to: Biological Trace Element Research} https://doi.org/10.1007/s12011-020-02562-5

The original version of this article unfortunately contained a mistake in Table 3 . The correct Table 3 is presented here.

The original article has been corrected.

Table 3 Methodological quality assessment of selected trials

\begin{tabular}{lllllll}
\hline Author & $\begin{array}{l}\text { Sequence } \\
\text { generation }\end{array}$ & $\begin{array}{l}\text { Allocation } \\
\text { concealment }\end{array}$ & $\begin{array}{l}\text { Blinding of } \\
\text { participants } \\
\text { and personnel }\end{array}$ & $\begin{array}{l}\text { Blinding of } \\
\text { outcome assessment }\end{array}$ & $\begin{array}{l}\text { Incomplete } \\
\text { outcome data }\end{array}$ & $\begin{array}{l}\text { Selective } \\
\text { reporting bias }\end{array}$ \\
\hline Licastro et al. [19] & Unclear & Unclear & Low & Low & Low & Low \\
biases
\end{tabular}

The online version of the original article can be found at https://doi.org/ $10.1007 / \mathrm{s} 12011-020-02562-5$

Dilina do Nascimento Marreiro dilina.marreiro@gmail.com

1 Department of Nutrition, Federal University of Piauí, Campus Minister Petrônio Portela, Teresina, Piauí, Brazil

2 Department of Nutrition, Federal University of Minas Gerais, Belo Horizonte, Minas Gerais, Brazil

3 Departamento de Nutrição, Universidade Federal do Piauí, Campus Ministro Petrônio Portela, Bairro Ininga, Teresina, Piauí 64049550 , Brazil 